\title{
Getting hedging right: a small-state perspective
}

\author{
Cheng-Chwee Kuik ${ }^{1}$
}

Received: 10 September 2021 / Accepted: 29 October 2021 / Published online: 23 November 2021

(C) The Institute of International and Strategic Studies (IISS), Peking University 2021

\begin{abstract}
Hedging is one of the more commonly used but least studied concepts in international relations. This essay conceptualizes hedging and operationalizes it to the alignment choices of Southeast Asian smaller states. I define hedging as insuranceseeking behavior under situations of high uncertainty and high stakes, where a rational state avoids taking sides and pursues opposite measures vis-à-vis competing powers to have a fallback position. I argue that while Washington and Beijing understandably dislike small-state hedging, they both overlook that it is the uncertainties stemming from their actions that push the weak to hedge. As uncertainties deepen, the non-great powers in Southeast Asia-as elsewhere-are compelled to hedge one way or another, even as the space to hedge is shrinking. Hedging is not a panacea and it entails its own problems. But acting out of their survival instincts, smaller states opt to hedge for as long as conditions compel. Unless US-China rivalry escalates into a direct conflict, or unless strategic certainty prevails, e.g., if Washington retreats or reduces its long-term commitment to Asia-raising certainty about the absence of a reliable aligned support—-then states will stop hedging and start bandwagoning with China; or if Beijing's actions directly threaten most actors on all major fronts - heightening certainty about an imminent, across-the-board dangerthen hedging will be replaced by balancing against China. Short of that, hedging is likely to persist, making ambiguities a defining theme of our time.
\end{abstract}

Keywords Hedging · Small states $\cdot$ Southeast Asia $\cdot$ United States · China · Uncertainty

Cheng-Chwee Kuik

cckuik@gmail.com

1 Institute of Malaysian and International Studies (IKMAS), National University of Malaysia (UKM), 43600 Bangi, Selangor, Malaysia 


\section{Introduction: (Mis)understanding hedging}

The term "hedging" was introduced into the international relations (IR) lexicon in the 1990s, when scholars and commentators began using the term to describe state behavior in which a country takes a middle position between the two straightforward strategies of balancing and "bandwagoning," displaying mixed elements of selective engagement, limited resistance, and partial deference (Lake 1996; Green 1999; Johnston and Ross 1999; Medeiros 2005; Goh 2005; Kuik 2008, 2020). Although hedging has been in use for decades, it remains a highly contentious and widely misunderstood concept in both policy and academic circles (Lim and Cooper 2015; Wang 2018; Ciorciari and Haacke 2019; Shambaugh 2020; Tan 2020; Jones and Jenne 2021).

In the policy world, hedging is viewed by many as contentious and even undesirable behavior. Big powers disapprove of such behavior. Smaller and secondary states deny they are hedging. Many government officials and observers dismiss hedging as speculative, passive, and unrealistic. Some even denounce hedging as dangerous, considering it a source of uncertainty and instability. The United States (USA) and China, who view themselves as the primary targets of hedging, have frequently expressed distaste for this behavior. They dismiss hedging as opportunistic and urge states who practice hedging to stop doing so. Weaker states-especially those in Southeast Asia, which is presently the main theater of US-China rivalry - are pressured by both Washington and Beijing to send clear and consistent signals. Small states are urged-either directly or indirectly-to fall in line and make the "correct" choice. The United States and its allies attempt to persuade smaller states to share the responsibility for "preserving the rulesbased order." China, on the other hand, lobbies the same countries to collaborate and "build a community of common destiny," while positioning itself as the "wave of the future."

Primarily because of the extensive misunderstanding that equates hedging with either indecisiveness or fence-sitting, or both, virtually all countries have avoided associating themselves with the term, let alone identifying with it. Typically, smaller and weaker states-particularly member states in the Association of Southeast Asian Nations (ASEAN) — choose to describe their policies as "nonaligned," "neutral" or "equidistant." Regardless of the label, in reality, smaller states do practice hedging in varying forms. Hedging is a policy that is implemented without pronouncement. Doing otherwise would invite unwanted pushback from the competing big powers, defeating the very purposes of this deliberately ambiguous act. The intended purposes for hedging are: developing robust relationships with both competing great powers (working toward the best outcomes), cultivating maximum protection to offset multiple risks under uncertainty (preparing for the worst scenarios), and, ultimately, keeping all options open for as long as possible.

In the field of IR, hedging is a widely used but under-theorized term. In 2005, Evan Medeiros lamented that hedging is "highly underdeveloped both in international relations theory and security studies literature." This holds true today. 
While a growing number of studies offer different conceptualizations and cover a range of diverse hedging cases (Tessman 2012; Tunsjo 2013; Jackson 2014; Fiori and Passeri 2015; Kuik 2016a, b; Hoo 2016; Murphy 2017; Koga 2018; Ciorciari 2019; Korolev 2019; Lim and Mukherjee 2019; Liao and Dang 2019; Pitakdumrongkit 2020; Chan 2020; Teo and Koga 2021; Cao 2021), there is still no consensus as to how hedging should be defined and applied. Jurgen Haacke (2019) observed that "as the literature on hedging has expanded, the concept's analytical value is no longer obvious." David Martin Jones and Nicole Jenne (2021) have criticized the dominant understandings of hedging, arguing that the term remains "a vague concept rendering it a residual category of foreign policy behavior."

This paper seeks to fill these gaps by offering a small-state perspective of hedging, developing a conceptualization of the term, and operationalizing it to the cases of Southeast Asian states' alignment behavior in the Indo-Pacific arena. The starting point for this paper is the assumption that hedging is not necessarily a well-calculated or cogently designed "strategy"; rather, it is best conceived of as instinctive behavior that prevails under high-stakes, high-uncertainty circumstances, i.e., when risks are real and potentially consequential to the prioritized values of a rationale state. Under such conditions, states hedge, just as rational actors engaged in other human activities - most notably, finance, farming, academics, and politics—would (Munn et al. 1991; Crompton 1997; Yoshinaka and Grose 2011).

To develop an operationalizable conceptualization that is applicable in IR, hedging is defined here as insurance-seeking behavior with three attributes: (a) an insistence on not taking sides or being locked into a rigid alignment; (b) attempts to pursue opposite or contradicting measures to offset multiple risks across domains (security, political, and economic); and (c) an inclination to diversify and cultivate a fallback position. These defining attributes enrich the "alignment" literature and contribute by enabling scholars to distinguish hedging from two strategies that are extensively discussed in the study of IR; "balancing" and "bandwagoning" (Waltz 1979; Walt 1985; Schweller 1994). Balancing and bandwagoning both involve: (i) a clear-cut choice in which a state sides with one power over another; (ii) unambiguous, single-directional measures of either countering a threat (in the case of balancing) or maximizing profits (and/or minimizing losses, in the case of bandwagoning); and (iii) putting all policy eggs in the aligned power's basket. Hedging differs from balancing and bandwagoning in all three attributes. Hedging is not only a "middle" position (as pointed out by the existing hedging literature), it is also an "opposite" and "fallback" position. Based on this three-point conceptualization, the ten ASEAN states - and, for that matter, many other states, including some US allies and partners-are "hedgers" in one way or another, although they hedge in different forms, to different degrees, and for different reasons. ${ }^{1}$ Accordingly, hedging is a type of alignment behavior, where a sovereign state positions itself between two or more

\footnotetext{
${ }^{1}$ For elaborations on these conceptual issues and empirical examples, see various chapters under "Light or heavy hedging: positioning between China and the United States," Joint U.S.-Korea Academic Studies 2015, edited by Gilbert Rozman; see also Kuik (2016a, b, 2020).
} 
competing powers, while navigating a broad range of risks and uncertainties under international anarchy.

This paper makes another contribution by engaging the ongoing debate on the causal relationship between hedging and international uncertainty, both theoretically and from the perspective of policy formulation. The central idea of this paper is that small-state hedging is caused by uncertainty, not the other way around. Critics who claim hedging is responsible for creating uncertainty and instability have got it wrong. Hedging does not cause big-power uncertainty; rather, it is a response to uncertainty (specifically, uncertainty about the principal threat and the principal support). The greater the uncertainty, the higher the tendency for rational actors to hedge. Southeast Asian countries welcomed former US President Barack Obama's pivot and rebalancing to Asia policy, only to see the subsequent administration, under President Donald Trump, reduce the US's multilateral commitments and downgrade partnerships. While smaller states now welcome President Joe Biden's "America is back" posture, they watch with quiet concern as the United States withdraws its forces from Afghanistan. Similarly, since the 1990s, Southeast Asian states have engaged with China's charm diplomacy bilaterally and multilaterally, only to see Beijing's charm turn into offensive acts since 2007-2008. While most states embrace China's Belt and Road Initiative (BRI) and its vaccine diplomacy, they are increasingly concerned about becoming over-dependent. They also ask quietly: Will China's assertiveness grow as its power increases? Considering the uncertainties brought about by the United States and China's actions in recent decades, hedging is the logical, if not inevitable, policy choice among smaller states.

The remainder of the paper proceeds in four sections. The first traces the roots of misunderstanding of small-state hedging to the perceptual gaps between the competing powers and the weaker states. The second unpacks small-state hedging by underscoring the seemingly contradictory elements of Southeast Asian states' alignment choices. The third analyzes the factors underpinning hedging behavior. The concluding section sums up by highlighting the reasons why hedging is likely to endure, even when big-power pressure is mounting and the maneuvering space for smaller states is narrowing.

\section{Glaring gaps}

The widespread misunderstanding of small-state hedging is partly rooted in the glaring gaps between what Washington and Beijing assume and what the smaller states-particularly those in Southeast Asia-actually want. On one hand, the United States expects smaller states to ally with it, assuming that they share Washington's threat perception of China and its strategic need to balance against growing Chinese power. On the other, China expects smaller states to bandwagon with it, assuming that as its relative power grows and as it regains its historical dominance, its weaker neighbors will adapt and adjust to an emerging reality. Both expectations are unrealistic under current conditions. These gaps-which arise not only from asymmetric capabilities, but also different outlooks, divergent values, and 
dissimilar political and developmental needs — must be acknowledged and addressed accordingly.

In the United States and some other Western countries, mainstream commentators assume that Southeast Asia and much of the rest of the world shares their strategic outlook; that is: China is the principal threat; the South China Sea dispute is the most pressing problem; and military tools-especially alliances among "likeminded" liberal democracies - are the principal means of responding to these seminal challenges. But these assumptions are too simplistic. Although smaller states in the region are indeed concerned about China's growing assertiveness and its impact on the regional status quo, they do not necessarily view China as the most pressing problem to be tackled immediately and at all costs. Instead, they view China as a permanent and increasingly profound factor that must be engaged (not confronted) to jointly manage regional issues and maintain regional prosperity, especially at a time when each country is still battling the COVID-19 pandemic and rebuilding its economy. For these and other reasons (elaborated below), Southeast Asian states want Chinese power to be constrained, not contained, and they do not want any single-sided alignment that would tie them with one camp against another. Countries in Southeast Asia-most of which are quasi-democracies and virtually all of which are post-colonial polities - know very well the dangers of over-emphasizing the democracy-authoritarian "divide" and over-privileging alliance-based "solutions," especially those that involve extra-regional powers (Kuik 2021b).

Smaller states also have problems with Beijing's stance. China's narrative typically attributes the current tensions solely to Washington and its allies' "Cold War mentality" and "containment" strategy, while overtly ignoring the smaller neighbors' growing anxiety about China's actions in Asian waters. China overestimates the appeal of its BRI economic statecraft, wrongly assuming that smaller states want only developmental benefits, even at the expense of their security and territorial interests. China underestimates the weaker states' sensitivity about their own autonomy, increasingly taking their deference for granted, while expecting its neighbors to accord it respect as its power grows. China also gives too much credence to its discourse of a "community of common destiny," mistakenly assuming that Asian nations' past shared suffering under Western colonialism and imperialism means a mutual desire for an Asian-led order in the future. China neglects the fact that, even though the majority of Southeast Asian states are alliance-adverse, almost all are keen to maintain countervailing forces to prevent the emergence of any hegemon in Asia, as long as confrontations are not provoked or polarization created.

Put bluntly, both the United States and China do not quite understand what Southeast Asian countries - and, for that matter, other smaller states-want. Even though both Washington and Beijing openly reiterate that they would not force smaller nations to take sides, they tacitly assume that weaker states will "eventually" side with a big power. They thus endeavor to win over the smaller states before the other power does. Such action-reaction is bound to escalate rivalry, increase pressures, and deepen small-state dilemmas.

Big powers tend to misinterpret smaller states' gestures to strengthen cooperation as a sign of the smaller states' alignment "choice"; they often overemphasize the utility of their respective prioritized statecraft (military security in the case of the 
United States; economic prosperity in the case of China); and they habitually ignore smaller states' longing for autonomy, neglecting what smaller states really want: their own survival; respect for their sovereignty; space to coexist and all-inclusive cooperation despite differences; as well as opportunities to maximize prosperity and other wellbeing that translates into greater ability on the part of the respective state's elites to perform domestic functions.

Examples of small-state preferences and anxieties abound. For instance, while Southeast Asian states welcome the Biden administration's renewed commitment to US allies and partners, they hesitate to fully align with a Washington-led coalition, especially when the coalition is increasingly explicit in targeting Beijing. Checking China's growing assertiveness is one thing; containing China is another. In addition, while many Southeast Asian states-like smaller states elsewhere-view a strong partnership with the United States and/or its allies as a core component of their external policies, they also insist on maintaining stable relations with China, cultivating multiple layers of partnerships with as many countries as possible, while guarding against regional polarization, the escalation of tensions, and big-power conflicts. An example of this nuanced approach is Indonesia and Malaysia's cautious response to the announcement of the Australia-UK-US (AUKUS) pact and the nuclear-powered submarine deal in September 2021. Indonesia expressed deep concern "over the continuing arms race and power projection in the region," calling on Australia "to maintain its commitment towards regional peace, stability and security in accordance with the Treaty of Amity and Cooperation" (Ministry of Foreign Affairs of the Republic of Indonesia 2021). Malaysia similarly expressed its reservations over the establishment of AUKUS to counter a rising China, warning that it will trigger "a nuclear arms race in the Indo-Pacific region" and "provoke other powers to act more aggressively in the region, especially in the South China Sea" (New Straits Times 2021).

Similarly, while the ASEAN states want to coexist and work with China for mutual benefits, they hesitate to fully bandwagon with Beijing for fear of becoming dependent and submissive. This is especially so when the proximate giant's growing power increasingly translates into growing assertiveness, even toward friendly governments and nations. For example, despite Rodrigo Duterte government's China-friendly policy, Beijing has continued its assertive activities in the disputed waters (e.g., in early 2021, hundreds of Chinese militia vessels maintained their months-long presence near the Philippines). Another example is Malaysia, a nation that has long been friendly toward China. It was the first ASEAN state to establish diplomatic ties with China, way back in 1974. As a close partner, Malaysia was instrumental in enmeshing China into ASEAN-based dialogue processes in the postTiananmen, post-Cold War era and collaborating with China to promote East Asiawide regional integration throughout the 1990s and 2000s, while adopting a low-key approach over the South China Sea disputes. But even Malaysia became the target of China's current assertiveness-16 People's Liberation Army Air Force aircraft intruded in the airspace near Malaysia's Sarawakian coast on May 31, 2021, ironically on the 47th anniversary of the establishment of Malaysia-China ties.

These acts undermine China's credibility, leaving virtually all smaller states to worry about whether and when they will be China's next targets (Razak et al. 2021). 
It is one thing to be non-confrontational, another to be subservient. Hence, while ASEAN as a group has avoided developing any links with the Quad and has avoided endorsing the Quad's Free and Open Indo-Pacific (FOIP) strategies, individual Southeast Asian states have all pragmatically maintained collaboration with each member of the Quad and their Indo-Pacific partners in Europe and elsewhere.

\section{How do states hedge (and what do they hedge against)?}

Singapore Prime Minister Lee Hsien Loong wrote in Foreign Affairs last summer: "Asia-Pacific countries do not wish to be forced to choose between the United States and China. They want to cultivate good relations with both" (Lee 2020). Ultimately, not taking sides while cultivating good relations with both competing powers is tied to an unspoken but fundamental policy aim: keeping a fallback position when situations are uncertain but stakes are high.

These elements are the essence of hedging. They require rational states to pursue multiple "just-in-case" acts: while collaborating with both powers on areas of converging interests wherever and whenever possible, they must also diversify partnerships, preserve independence, and pursue mutually counteracting acts of selective defiance and selective deference, all with an eye to mitigating and offsetting multiple risks associated with uncertainties (Kuik 2020). If situations are certain and stakes are low, hedging would not be necessary. But when stakes are high and situations are uncertain-e.g., when big powers' actions might significantly harm or help a state's interests, and when it is unclear what the principal threat is and who the principal, reliable patron is-then hedging is imperative.

These themes are recurring in Southeast Asia (and elsewhere), across countries and across time, transcending leaders and governments. Contrary to the conventional wisdom that smaller states choose to align with the United States to hedge against China, in reality, Southeast Asian hedging is not about being against any particular, specific actor, but against multiple broad risks. These include: the undesirable but possible dangers of an increasingly aggressive China, an uncertain US long-term commitment, unpredictable US-China relations, and a big-power conflict that no one wants but cannot be dismissed. Driven by a desire-a survival instinctto avoid and mitigate such dangers, virtually all countries have sought to pursue purposefully contradictory acts to keep options open. Hence, when a smaller state defies and pushes back a big power's act that harms its own interests, it typically does so selectively-limiting and offsetting its defiance with the opposite acts of selective deference and cooperation, making sure that its defiance will not escalate into an allout confrontation. The reverse is true: when a smaller state seeks to collaborate and defer to a stronger power to maximize interests or forge closer relations, it typically does so selectively, counteracting its deference and cooperative acts either by acts of defiance in other areas, or by stepping up its partnerships with the other power(s), thereby underscoring its independence and preserving its autonomy.

Vietnam, for instance, has publicly and persistently pushed back against Beijing by confronting Chinese maritime assertiveness and by cultivating countervailing forces with Washington and other partners to constrain China. But Vietnam has 
done so without burning its bridges, as evidenced by Hanoi's offsetting acts: maintaining close party-to-party relations with the CCP, while declaring its "four no's" aimed at reassuring and deterring Beijing simultaneously (i.e., no military alliances, no foreign military bases in Vietnam, no reliance on one country to fight another, no using force or threatening to use force). In late August 2021, about a month after US Secretary of Defense Lloyd Austin's visit and shortly before the arrival of US Vice President Kamala Harris in Hanoi, Vietnamese Prime Minister Pham Minh Chinh met with Chinese Ambassador Xiong Bo. At the meeting, the Vietnamese leader declared that "Vietnam does not align itself with one country against any other."

Indonesia has also hedged by pursuing open defiance and partial deference. Jakarta, for instance, has responded to Beijing's growing assertiveness by conducting a series of high-profile military exercises in response to China's growing presence near its Natuna Islands and by developing high-level strategic ties with more defense partners. But, it is doing so side-by-side with opposite acts: developing an increasingly institutionalized strategic partnership with China, selectively embracing the BRI, and keeping silent on the Xinjiang issue (despite Indonesia being the world's largest Muslim-majority country). The year 2021 marks numerous examples of Jakarta's hedging diplomacy. In May 2021, Indonesia and China held joint naval exercises near Jakarta; in June, they held their inaugural meeting of the bilateral, high-level dialogue. In August, Indonesia and the United States launched their largest island defense military drills near the islands of Sumatra, Sulawesi, and Borneo. Indonesia has also maintained 2-plus-2 security talks with Australia and Japan, respectively. Indonesia had entered into similar arrangements with Germany in April 2021.

Singapore, too, has hedged persistently. Throughout the post-Cold War era, the tiny, vulnerable city-state has cultivated multiple approaches to cope with uncertainties and offset multiple risks that might endanger its security, prosperity, and autonomy. The island-state has hosted US military assets since 1990, maintains a robust strategic alignment with Washington (indeed the deepest defense and security partnership in Southeast Asia), while defying Beijing's will at several junctures (Lee Hsien Loong's insistence on visiting Taiwan in 2004 and Singapore's stance on the 2016 arbitral tribunal's ruling on the South China Sea, for example). At the same time, however, the city-state has also pragmatically forged productive economic ties and maintained close dialogue and relations with China, pursued a forward and wide-ranging engagement with the BRI, and-like other smaller states in the region-made it a point to expand defense ties with China, even while continuing to engage and explore a wide range of security partnerships (including cyber and supply chain cooperation) with other powers.

Other ASEAN states have also pursued hedging in various forms, albeit more lightly-by emphasizing cooperative and deferential acts while displaying defiance vis-à-vis China only in an indirect, low-key manner. Malaysia, for instance, despite its claimant status in the South China Sea and its longstanding strategic ties with the United States and other Western powers, has chosen to highlight the mutually beneficial aspects of its increasingly robust and comprehensive partnership with China, downplaying security concerns and avoiding a confrontational approach, a stark contrast to its openly adversarial posture against Beijing in the 1950s and 1960s. 
Similarly, the Philippines under Duterte and Brunei-the other claimant states in the South China Sea-have hedged lightly. Cambodia, which prefers to prioritize its cooperative and productive partnership with China (thereby pleasing Beijing), has opted to hedge quietly by diversifying its development and defense relations with Japan and other actors (thereby displeasing Beijing).

By pleasing and displeasing China concurrently (and doing both selectively and partially), the seemingly contradictory acts serve to hedge multiple risks externally and internally, thereby enabling the smaller states to maximize cooperative space and optimize interests without rigidly locking themselves into irreversible positions amid an uncertain power structure.

In short, virtually all ASEAN states have hedged persistently throughout the postCold War decades. They have avoided placing all their eggs in China's or, for that matter, any power's basket. Instead, they have diversified, remained equidistant, and cultivated space to ensure the involvement of other powers in regional affairs (Kuik 2016a, 2020). Smaller states are not necessarily powerless actors-they do have considerable agency to shape their external environment.

And it is not just the Southeast Asian states who hedge. Second-tier big powers, including some US allies and partners, have also hedged in varying forms, some more quietly and intermittently than others, as each of them responds to changing structural conditions and domestic needs (see Rozman 2015; Kuik 2020). For example, in 2018, at the height of the unpredictable Trump years, Japan under Shinzo Abe moved to ameliorate relations with China, even as it maintained its alliance with Washington as the core of its Plan A while simultaneously pursuing multiple Plans B, such as promoting "free and open" Quad partnerships with likeminded nations, reviving the Quad, and courting ASEAN states. This multi-pronged policy has been, by and large, continued by Abe's successors, Yoshihide Suga (September 2020-October 2021) and Fumio Kishida (since October 2021), even though Tokyo has increasingly shown signs of returning to near-balancing since the advent of the Biden administration.

Another longstanding US ally in Asia, South Korea, has hedged more persistently, and on multiple fronts. It refrained from joining the Quad, kept its distance from the Quad's Indo-Pacific strategies and, unlike other US allies, avoided direct involvement in the South China Sea disputes. Even as President Moon Jae-in launched his "New Southern Policy" to diversify and enhance South Korea's partnerships with ASEAN and India in the wake of Chinese economic retaliation over the Terminal High Altitude Area Defense (THAAD) system, he has sought to cultivate a stable and productive relationship with Beijing.

India displays its hedging more intermittently, even in the wake of the 2017 stand-off with China on the Doklam plateau. In 2018, Indian Prime Minister Narenda Modi met with Chinese President Xi Jinping and institutionalized an informal summit with Beijing, just before attending the Western-backed Shangri-La Dialogue to deliver a keynote speech on New Delhi's vision of the Indo-Pacific as a "free, open, and inclusive" region. Modi's insistence that India is non-aligned has led him to keep the Quad as a non-alliance partnership, despite growing Indian-Chinese tensions along their Himalayan border (including the Galwan Valley clash in 2020) and an increasing push from Quad members to further strengthen their group. 
Even European countries hedge. While France, Germany, and the Netherlands released policy documents unveiling their respective strategies for the Indo-Pacific region and underscoring their increased focus on Asia, these moves do not converge neatly with those of the United States and other Quad members. Germany's IndoPacific guidelines, for instance, eschew mentioning the Quad, reflecting its reluctance to be entrapped in a potentially divisive power confrontation between the Quad and China. Then German Chancellor Angela Merkel and French President Emmanuel Macron jointly pushed through the EU-China investment deal in late December 2020, despite the other member states' preference for a more balanced deal and Washington's expressed wish to coordinate with the EU on a tougher transatlantic approach to tackle China. More recently, in August 2021, while Germany dispatched its frigate, Bayern, on a 6-month long mission to the South China Sea (thereby defying China), it also simultaneously sought to dock the Bayern at Shanghai (thereby signaling a benign, not-against-you intent). ${ }^{2}$

\section{Risks and realpolitik: Why do smaller states hedge?}

The above examples of hedging by Southeast Asian states (as well as US allies and partners) should not surprise anyone. The non-great powers hedge because they must. The smaller states' multi-pronged, just-in-case approach is simply realpolitik; a self-help act of mitigating risks and making sure that all options are open, as uncertainty grows.

Presently, the circumstances in Asia are increasingly uncertain, primarily because of the great powers' actions and interactions. In the eyes of the smaller states, the United States and China have both displayed fluctuating commitments over the past decade, raising concerns about US credibility, China's future intentions, and the trajectory of their future relations. These have, in effect, multiplied the systemic risks, pushing smaller states to deepen their hedge.

Southeast Asian countries were convinced by the Obama administration's commitments to multilateralism and ASEAN-based regionalism. Then Trump scrapped the Trans-Pacific Partnership on the first day of his presidency and skipped key ASEAN-led summits in subsequent years. Hence, even as Southeast Asian leaders welcome a more credible and predictable Biden administration, they also ask silently, "Will it be different this time? Will the situation change, again, after four years?" Pandora's Box has been opened and will not be closed so readily.

Likewise, Southeast Asian states were convinced by China's "charm offensive" (Kurlantzik 2007) throughout the 1990s and 2000s. Then Beijing turned assertive and even aggressive, especially over the South China Sea disputes, and even to its friends and longstanding partners, as noted. Hence, when Southeast Asian leaders express appreciation for Beijing's pledges to speed up efforts to meet their needs in vaccines, infrastructure, and economic recovery, they also ask: "Will China show creeping hegemony as its power increases in the coming years? To what extent, in

\footnotetext{
${ }^{2}$ However, the Bayern's planned port visit was denied by China.
} 
what scope, and at what price, will China continue to be a principal supplier of the regional and global public goods required by the smaller states in the post-pandemic era?".

These questions reflect the smaller states' ambivalence and mixed perceptions vis-à-vis both the United States and China. Both powers are indispensable sources of support for the smaller states to achieve regional and national prosperity, stability, and security. However, both are also sources of uncertainty and are unreliable in their own ways. Neither power is a one-size-fits-all solution; neither is a single source of external challenges.

Hence, from the smaller states' viewpoints, the competing powers' growing rivalries and increasing tendencies to induce the regional countries to stop hedging and start siding with one power against another would only increase structural risks: creating "we-them" polarization, provoking premature confrontation, and perpetuating a vicious cycle of hegemonic conflicts. These risks are unjustified, unnecessary, and counterproductive.

Structural logics aside, there are domestic-level factors that underpin the smaller states' hedging. All Southeast Asian state elites are more concerned about their own survival and governance tasks at home. They tend to view their own domestic challenges as more critical politically. Creating jobs, delivering economic growth, ensuring stability, managing internal conflicts, and/or winning elections are the more vital pathways to preserving the ruling elites' legitimacy and enhancing their authority. Their perceptions of stakes and solutions are tied to this wide range of domestic tasks, rather than to a single issue.

Maintaining a stable external environment and productive relations with all powers and key actors have become more salient to the elites' domestic agenda in the pandemic era, as regional states prioritize vaccination, economic revitalization, and growth prospects. Beijing is vital for the accomplishment of these goals, and this trend will continue. Last year, ASEAN replaced the EU as China's largest trading partner. This interdependence is likely to grow, especially after the signing of the Regional Comprehensive Economic Partnership (RCEP) in November 2020, a freetrade agreement involving not only ASEAN and China, but also Japan, South Korea, Australia, and New Zealand, covering nearly one-third of the world's population and global trade.

However, from a small-state perspective, there is a thin line between interdependence and dependence, especially when it comes to living with a proximate giant. Precisely because China is growing in importance (along with growing risks of dependence and subservience) and becoming more assertive in its behavior, the Southeast Asian states_out of self-help—are deepening their hedging approach by seeking greater and wider diversification on both strategic and developmental fronts. For smaller states, hedging is not opportunistic, it is pragmatic. Hedging is not indecisiveness, it is a conscious choice, albeit an undeclared one.

Looking ahead, the imperative of realpolitik means the smaller states' alignment positions and global order in the future will be determined not only on the "highpolitics" in the military security realms, but also "low-politics" in the non-military domains. These are the twin chessboards of Asian geopolitics in this century (Kuik 2021a). Thus far, the United States and China both have mixed scores on the 
two chessboards. Washington has prioritized the first chessboard over the second, whereas Beijing appears to rely more on using its BRI statecraft, bilateral diplomacy, and multilateral involvement to win the hearts and minds of the smaller states in Southeast Asia and elsewhere, presumably hoping that its score on the second chessboard might offset the adverse impact of its assertive actions on the first.

These existing approaches provide the respective powers with some geopolitical mileage in the short term, but neither approach will work effectively over the long run. Beijing should not overestimate the impact of its economic statecraft and its pandemic diplomacy, and it should not underestimate the smaller neighbors' anxieties about its security actions and maritime assertiveness, including its new maritime law. The United States and its allies, on the other hand, must focus beyond maritime security and military partnerships - the main activities of the US and Quad's FOIP strategies. Washington needs to do more than performing Freedom of Navigation Operations (FONOPs), more than engaging in military exercises, and more than providing defense assets to regional countries. Although significant, these endeavors are far from sufficient to win wholehearted supporters in Southeast Asia. While they may help constrain China's maritime adventures and contribute to regional stability, these are only part of what the smaller states want. The smaller states' other priorities include economy, healthcare, infrastructure development, etc., as noted. The US foreign policy establishment has long accorded these low politics issues relatively less attention. The Blue Dot Network and the Build Back Better World, years and months after their announcements, have remained as plans, rather than actions.

Washington must recognize that, in the post-pandemic era, geoeconomics are geopolitics. Beijing's steadily growing influence in Asia and elsewhere over the past decades has more to do with the use of non-coercive instruments on the low-politics chessboard: infrastructure, institutions, and interdependence via trade and other forms of connectivity-building. Despite all the problems associated with the BRI, China's economic and diplomatic statecraft made headway in Southeast Asia and beyond for one important reason-China is one of the key suppliers for what the ruling elites prioritize: the required support for development, growth, and other bases of elite authority at home. This is true not only for Cambodia, Laos, and Myanmar, but also for such relatively higher-income countries as Brunei, Malaysia, Singapore, and to some extent, the more populous countries of Indonesia and the Philippines as well.

While these realities might not necessarily push the Southeast Asian nations to willingly accept China's domination (in fact, the opposite is true: they deepen the smaller states' determination to hedge), they do induce the smaller states to pay more attention to Beijing's "core interests" (Taiwan, Hong Kong, Tibet, Xinjiang), show greater collaboration with China (e.g., such China-backed arrangements as the Asian Infrastructure Investment Bank, Xiangshan Forum, Lancang-Mekong Cooperation), as well as exhibit varying degrees of resentment and resistance when their own interests are directly challenged by Beijing's actions.

The extent and manner in which smaller states hedge by recalibrating and even resisting the big power's tendency to impose its will on them is a complex matter. It depends not only on the smaller states' policy and the giants' mercy, but also on the availability of credible and reliable power(s) that can supply alternative sources of 
public and private goods required by the ruling elites. These goods are not confined to such high-politics matters as stability and security in the South China Sea, but extend to low-politics stakes: development, education, healthcare, technology and various aspects of domestic resilience. The future of the Asian order, hence, will be determined on both the military and non-military chessboards.

\section{Conclusion}

To conclude, hedging is an instinctive, self-help behavior, especially for smaller states. When stakes are high and circumstances uncertain (brought about by the deepening and widening US-China rivalry), rational actors will hedge by pursuing multiple insurance-providing measures. They seek to avoid rigid, irreversible commitments vis-à-vis the competing powers (as when Southeast Asian states insist on not taking sides between Washington and Beijing) and clear-cut actions (as when smaller states take deliberately contradictory actions to offset different risks, pleasing and displeasing both the United States and China, while displaying selective deference to and defiance of all powers). They do so with their eyes on keeping options open for as long as possible.

The smaller states in Southeast Asia (and elsewhere)—which are more preoccupied with resolving pressing and myriad challenges at home than teaming up with one external power against another-see greater fluidity, irresolution, and ambivalence in their external environment. Instead of seeing a principal patron and a principal threat (as was the case during the early decades of the Cold War period), they no longer hold such clear-cut, straightforward perceptions. That is, while many ASEAN states continue to view the United States and its allies as indispensable partners, they also perceive them as insufficient and uncertain partners, providing much needed security support and economic opportunities, but also posing the risks of abandonment, entrapment, marginalization, political challenges, and other tradeoffs. The smaller states' perceptions of China are even more ambivalent: a vital source of economic and political partnerships but a security concern (especially those with overlapping territorial claims) likely to lead to economic dependency, political subservience, and domestic resentments over the long run.

Under such circumstances, pure-balancing or pure-bandwagoning are both nonstarters. Balancing is unlikely, primarily because none of the weaker states is certain if the United States and its allies will come to their defense, and nobody knows if Washington will remain as a "resident power" in Asia, how, and for how long. Bandwagoning is unlikely, mainly because no state is certain if an even more powerful China will be benevolent or malevolent, and nobody knows if the current gains involve unacceptable future risks, how so, and at what price. Perhaps, more fundamentally, such clear-cut options are unlikely because no state is certain which power will prevail in the future, when, and how, and nobody knows whether the current big-power competition will evolve into détente (will big powers make a deal at our expense?) or escalate into conflict (when that happens, will we be the first to suffer?). 
Hedging, by comparison, is a more logical choice. Although far from being the best approach, hedging provides some room for weaker states to strike a balance between prioritized benefits and unavoidable costs. It allows smaller states to minimize risks and maximize returns, in ways that enable the governing elites to concentrate on their domestic tasks, without speculating who will be the more dominant power in the future.

Enabling Southeast Asian states to hedge and keep their strategic autonomy iscounter-intuitively - not only good for the smaller states, but also good for all powers and actors. Understandably, this is not an ideal situation for any of the competing powers, but precisely because this is not the best scenario for any of the rivaling powers, it is the second-best option for all of them. Fundamentally, small-state hedging means that none of the ASEAN countries wants to align with one power against another under the current circumstances. This helps ensure Southeast Asian neutrality, prevents regional polarization, and maintains regional stability, thereby keeping the space, platforms, and prospects for countries of diverse interests and identities to continue forging inclusive, region-wide cooperation (e.g., the conclusion of RCEP), even in the face of growing power rivalries and the ongoing pandemic crisis.

Acknowledgements The author gratefully acknowledges support from the Korea Foundation Policy Oriented Project Grant no. 1024000-101. He thanks Thomas J. Christensen, John D. Ciorciari, Fong Chin Wei, Francis Fukuyama, Evelyn Goh, Jurgen Haacke, David Han, He Kai, Heng Yee Kuang, Karl D. Jackson, John Jenner, Khong Yuen Foong, Khor Swee Kheng, Lai Yew Meng, David M. Lampton, Ann Marie Murphy, Ngeow Chow Bing, Pu Xiaoyu, Abdul Razak Ahmad, and the three anonymous reviewers for their valuable feedback on various earlier versions of this article. He also thanks Fikry A. Rahman and Izyan Hay for their superb research assistantship. The usual caveats apply.

Funding This article is supported by the Korea Foundation Policy Oriented Project Grant no. 1024000-101.

\section{Declarations}

Conflicts of interest No conflict of interest.

\section{References}

Abdul Razak Ahmad, Kuik Cheng-Chwee, and Lai Yew Meng. 2021. PLA overflight near Malaysian airspace: a precarious provocation. Fulcrum. https://fulcrum.sg/pla-overflight-near-malaysian-airsp ace-a-precarious-provocation/. Accessed 9 Sept 2021.

Cao, Wei[曹玮]. 2021. Taking sides or hedging: Asia-Pacific countries' choices amid China-U.S. strategic competition (选边还是对冲——中美战略竞争背景下的亚太国家选择). World Economics and Politics(世界经济与政治) 2: 47-77.

Chan, Lai-Ha. 2020. Strategic hedging: a 'third way' for Australian foreign policy in the Indo-Pacific. Asia Policy 15(3): 87-112.

Ciorciari, John D. 2019. The variable effectiveness of hedging strategies. International Relations of the Asia-Pacific 19(3): 523-555.

Ciorciari, John D., and Jürgen Haacke. 2019. Hedging in international relations: an introduction. International Relations of the Asia-Pacific 19(3): 367-374.

Crompton, Peter. 1997. Hedging in academic writing: some theoretical problems. English for Specific Purposes 16(4): 271-287. 
Antonio, Fiori, and Andrea Passeri. 2015. Hedging in search of a new age of non-alignment: Myanmar between China and the USA. The Pacific Review 28(5): 679-702.

Goh, Evelyn. 2005. Meeting the China challenge: the U.S. in Southeast Asian regional security strategies. Policy Studies, No. 16. Washington, D.C.: East-West Center. https://www.eastwestcenter.org/ publications/meeting-china-challenge-us-southeast-asian-regional-security-strategies. Accessed 6 Jan 2006.

Green, Michael J. 1999. Managing Chinese power: the view from Japan. In Engaging China: the management of an emerging power, ed. Alastair Iain Johnston, and Robert S. Ross, 152-175. New York: Routledge.

Haacke, Jürgen. 2019. The concept of hedging and its application to Southeast Asia: a critique and a proposal for a modified conceptual and methodological framework. International Relations of the Asia-Pacific 19(3): 375-417.

Hoo, Tiang Boon. 2016. The hedging prong in India's evolving China strategy. Journal of Contemporary China 25(101): 792-804.

Jackson, Van. 2014. Power, trust, and network complex: three logics of hedging in Asian security. International Relations of the Asia-Pacific 14(3): 331-356.

Johnston, Alastair Iain, and Robert S. Ross (eds.). 1999. Engaging China: the management of an emerging power. New York: Routledge.

Jones, David Martin, and Nicole Jenne. 2021. Hedging and grand strategy in Southeast Asian foreign policy. International Relations of the Asia-Pacific. https://doi.org/10.1093/irap/lcab003.

Koga, Kei. 2018. The concept of “hedging” revisited: the case of Japan's foreign policy strategy in East Asia's power shift. International Studies Review 20(4): 633-660.

Korolev, Alexander. 2019. Shrinking room for hedging: system-unit dynamics and behavior of smaller powers. International Relations of the Asia-Pacific 19(3): 419-452.

Kuik, Cheng-Chwee. 2008. The essence of hedging: Malaysia and Singapore's response to a rising China. Contemporary Southeast Asia 30(2): 159-185.

Kuik, Cheng-Chwee. 2016a. How do weaker states hedge? Unpacking ASEAN States' alignment behavior towards China. Journal of Contemporary China 25(100): 500-514.

Kuik, Cheng-Chwee. 2016b. Malaysia between America and China: what do weaker states hedge against? Asian Politics \& Policy 8(1): 115-177.

Kuik Cheng-Chwee. 2020. Hedging in post-pandemic Asia: what, how, and why? The Asan Forum. June 6, 2020. https://theasanforum.org/hedging-in-post-pandemic-asia-what-how-and-why/. Accessed 6 June 2020.

Kuik, Cheng-Chwee. 2021a. The twin chessboards of U.S.-China rivalry: impact on the geostrategic supply and demand in post-pandemic Asia. Asian Perspective 45(1): 157-176.

Kuik, Cheng-Chwee. 2021b. Southeast Asian states and ASEAN: a center of courtships and cooperation. In The International Relations of Asia, 3rd ed., ed. David Shambaugh. Lanham: Rowman and Littlefield (Forthcoming).

Kurlantzik, Joshua. 2007. Charm offensive: how China's soft power is transforming the world. Binghamton: Yale University Press.

Lake, David A. 1996. Anarchy, hierarchy, and the variety of international relations. International Organization 50(1): 1-33.

Lee, Hsien Loong. 2020. The endangered Asian century: America, China, and the perils of confrontation. Foreign Affairs 99(4): 51-64.

Liao, Jessica C., and Ngoc-Tram Dang. 2019. The nexus of security and economic hedging: Vietnam's strategic response to Japan-China infrastructure financing competition. The Pacific Review. https:// doi.org/10.1080/09512748.2019.1599997.

Lim, Darren J., and Rohan Mukherjee. 2019. Hedging in South Asia: balancing economic and security interests amid Sino-Indian competition. International Relations of the Asia-Pacific 19(3): 493-522.

Lim, Darren J., and Zack Cooper. 2015. Reassessing hedging: the logic of alignment in East Asia. Security Studies 24(4): 696-727.

Medeiros, Evan S. 2005. Strategic hedging and the future of Asia-Pacific stability. The Washington Quarterly 29(1): 145-167.

Ministry of Foreign Affairs of the Republic of Indonesia. 2021. Statement on Australia's nuclear-powered submarines program. September 17, 2021. https://kemlu.go.id/portal/en/read/2937/siaran_pers/state ment-on-australias-nuclear-powered-submarines-program. Accessed 18 Sept 2021.

Munn, Glenn G., F.L. Garcia, and Charles J. Woelfel. 1991. Encyclopedia of banking and finance, 9th ed. New York: McGraw-Hill. 
Murphy, Ann Marie. 2017. Great power rivalries, domestic politics and Southeast Asian foreign policy: exploring the linkages. Asian Security 13(3): 165-182.

New Straits Times. 2021. Malaysia concerned with trilateral AUKUS security pact. September 18, 2021. https://www.nst.com.my/news/nation/2021/09/728403/malaysia-concerned-trilateral-aukus-secur ity-pact. Accessed 18 Sept 2021.

Pitakdumrongkit, Kaewkamol. 2020. What causes changes in international governance details? An economic security perspective. Review of International Political Economy. https://doi.org/10.1080/ 09692290.2020.1819371.

Rozman, Gilbert (ed.). 2015. Light or heavy hedging: positioning between China and the United States. In Joint U.S.-Korea Academic Studies 2015, 1-73. Washington, DC: Korea Economic Institute of America. http://www.keia.org/sites/default/files/publications/kei_jointus-korea_2015_final_lowres. pdf. Accessed 23 Dec 2015.

Schweller, Randall L. 1994. Bandwagoning for profit: bringing the revisionist state back in. International Security 19(1): 72-107.

Shambaugh, David. 2020. Where great powers meet: America and China in Southeast Asia. Oxford: Oxford University Press.

Tan, See Seng. 2020. Consigned to hedge? Southeast Asia and America's "free and open Indo-Pacific" strategy. International Affairs 96(1): 131-148.

Teo, Ang Guan, and Kei Koga. 2021. Conceptualizing equidistant diplomacy in international relations: the case of Singapore. International Relations of the Asia-Pacific. https://doi.org/10.1093/irap/lcab0 11.

Tessman, Brock. 2012. System structure and state strategy: adding hedging to the menu. Security Studies 21(2): 192-231.

Tunsjo, Oystein. 2013. Security and profit in China's energy policy: hedging against risk. New York: Columbia University Press.

Wang, Dong[王栋]. 2018. Hedging in international relations: the case of the Asia Pacific countries (国 际关系中的对冲行为研究——亚太国家为例). World Economics and Politics (世界经济与政 治) 10: 21-49.

Yoshinaka, Antoine, and Christian R. Grose. 2011. Ideological hedging in uncertain times: inconsistent legislative representation and voter enfranchisement. British Journal of Political Science 41(4): 765-794.

Walt, Stephen M. 1985. Alliance formation and the balance of world power. International Security 9(4): 3-43.

Waltz, Kenneth N. 1979. Theory of international politics. Reading: Addison-Wesley. 